${ }^{1}$ Near East University, Nicosia, Turkey, Peoples' Friendship University of Russia, Moscow, Russia;

${ }^{2}$ Institute of Mathematics and Mathematical Modeling, Almaty, Kazakhstan;

${ }^{3}$ Omar Al-Mukhtar University, El-Beida, Turkey

(E-mail: allaberen.ashyralyev@neu.edu.tr)

\title{
Numerical solution of the nonlocal boundary value problem for elliptic equations
}

In the present paper a second order of accuracy two-step difference scheme for an approximate solution of the nonlocal boundary value problem for the elliptic differential equation $-v^{\prime \prime}(t)+A v(t)=f(t)$ $(0 \leq t \leq T), v(0)=v(T)+\varphi, \int_{0}^{T} v(s) d s=\psi$ in an arbitrary Banach space $E$ with the strongly positive operator $A$ is presented. The stability of this difference scheme is established. In application, the stability estimates for the solution of the difference scheme for the elliptic differential problem with the Neumann boundary condition are obtained. Additionally, the illustrative numerical result is provided.

Keywords: stability; positive operators; elliptic equation; numerical results, two-step difference scheme.

\section{Introduction}

The well-posedness in various Banach spaces of the local boundary value problem for the elliptic equation

$$
-v^{\prime \prime}(t)+A v(t)=f(t)(0 \leq t \leq T), v(0)=v_{0}, v(T)=v_{T}
$$

in an arbitrary Banach space $E$ with the positive operator $A$ and its related applications have been investigated by many researchers (see, for example, [1-3] and the references given therein).

In mathematical modeling, elliptic equations are used together with local boundary conditions specifying the solution on the boundary of the domain. In some cases, classical boundary conditions cannot describe process or phenomenon precisely. Therefore, mathematical models of various physical, chemical, biological or environmental processes often involve nonclassical conditions. The well-posedness of various nonlocal boundary value problems for partial differential and difference equations has been studied extensively by many researchers (see, e.g., [4-21] and the references given therein).

In the present paper the abstract nonlocal boundary value problem for differential equation of elliptic type

$$
-v^{\prime \prime}(t)+A v(t)=f(t) \quad(0 \leq t \leq T), v(0)=v(T)+\varphi, \int_{0}^{T} v(s) d s=\psi
$$

in the arbitrary Banach space $E$ with the positive operator $A$ is considered. The second order of approximation two-step difference scheme

$$
\left\{\begin{array}{l}
-\frac{u_{k+1}-2 u_{k}+u_{k-1}}{\tau^{2}}+A u_{k}=f_{k}, f_{k}=f\left(t_{k}\right), t_{k}=k \tau, 1 \leq k \leq N-1, N \tau=T ; \\
u_{0}=u_{N}+\varphi, \sum_{i=1}^{N} u_{i} \tau=\psi
\end{array}\right.
$$

for the approximate solution of problem (2) is presented. The stability of this difference scheme is established. In application, the stability estimates for the solution of the difference scheme for the elliptic differential problem with the Neumann boundary condition are obtained. Additionally, the illustrative numerical result is provided. 


\section{Auxiliary results}

In this section, we give some auxiliary statements from [1] which will be useful in the sequel. We consider the second order of accuracy difference scheme

$$
\begin{gathered}
-\frac{u_{k+1}-2 u_{k}+u_{k-1}}{\tau^{2}}+A u_{k}=f_{k}, f_{k}=f\left(t_{k}\right), t_{k}=k \tau, 1 \leq k \leq N-1, N \tau=T, \\
u_{0}=v_{0}, u_{N}=v_{T} .
\end{gathered}
$$

of the approximate solution of the boundary value problem (1). This problem is uniquely solvable, and the following formula holds

$$
\begin{gathered}
u_{k}=\left(I-R^{2 N}\right)^{-1}\left\{\left(R^{k}-R^{2 N-k}\right) u_{0}+\right. \\
+\left(R^{N-k}-R^{N+k}\right) u_{N}-\left(R^{N-k}-R^{N+k}\right)(I+\tau B) \times \\
\times(2 I+\tau B)^{-1} B^{-1} \sum_{i=1}^{N-1}\left(R^{N-i}-R^{N+i}\right) f_{i} \tau+ \\
+(I+\tau B)(2 I+\tau B)^{-1} B^{-1} \sum_{i=1}^{N-1}\left(R^{|k-i|}-R^{k+i}\right) f_{i} \tau, 1 \leq k \leq N-1,
\end{gathered}
$$

where

$$
B=B(\tau, A)=\frac{\tau A}{2}+\sqrt{\left(\frac{\tau A}{2}\right)^{2}+A}, R=R(\tau B)=(I+\tau B)^{-1} .
$$

Note that $B(\tau, A) \neq A^{\frac{1}{2}}$ but then $B(\tau, A) \rightarrow A^{\frac{1}{2}}$ as $\tau \rightarrow 0$ and it has same spectral properties of $A^{\frac{1}{2}}$ under some assumptions for $A$.

Let us denote by $C_{\tau}(E)=C\left([0, T]_{\tau}, E\right)$ the normed space of grid functions $\varphi^{\tau}=\left\{\varphi_{k}\right\}_{k=0}^{N}$ for fixed $\tau=\frac{T}{N}$ with the norm

$$
\left\|\varphi^{\tau}\right\|_{C_{\tau}(E)}=\max _{0 \leq k \leq N}\left\|\varphi_{k}\right\|_{E} .
$$

From the formula (5) it follows that the investigation of the stability and well-posedness of difference scheme (4) relies in an essential manner on a number of properties of the powers of the operator $(I+\tau B)^{-1}$. We were not able to obtain the estimates for powers of the operator $(I+\tau B)^{-1}$ in the general cases of operator $A$. We begin by deriving some estimates for powers of the operator $(I+\tau B)^{-1}$ with a strongly positive operator $A$ in a Banach space $E$.

Lemma 1. Let $A$ be a strongly positive operator in a Banach space $E$. Then $-A$ is a generator of the analitic semigroup $\exp \{-t A\}(t \geq 0)$ with exponentially decreasing norm, when $t \longrightarrow+\infty$, i. e. we have the following estimates

$$
\begin{gathered}
\|\exp \{-t A\}\|_{E \longrightarrow E} \leq M e^{-t \delta}(t>0) ; \\
\|t A \exp \{-t A\}\|_{E \longrightarrow E} \leq M e^{-t \delta}(t>0)
\end{gathered}
$$

for $1 \leq M<+\infty, 0<\delta<+\infty$. Here $M$ does not depend on $\tau$.

Lemma 2. Let $-A$ be a generator of the analytic semigroup $\exp \{-t A\}(t \geq 0)$ with exponentially decreasing norm, when $t \longrightarrow+\infty$. Then the following estimates hold for any $k \geq 1$ :

$$
\begin{gathered}
\left\|(\lambda I+\tau B)^{-k}\right\|_{E \rightarrow E} \leq M\left[\lambda+\tau^{2} a(A)\right]^{-k} ; \\
\left\|k \tau B(I+\tau B)^{-k}\right\|_{E \rightarrow E} \leq M,
\end{gathered}
$$

where $M$ does not depend on $\tau$.

We have the following results.

Theorem 3. Let $A$ be a strongly positive operator in a Banach space $E$. Then the difference problem (4) is stable in $C_{\tau}(E)$. For the solution of the difference problem (4) the following stability inequality is satisfied:

$$
\left\|u^{\tau}\right\|_{C_{\tau}(E)} \leq M\left[\left\|f^{\tau}\right\|_{C_{\tau}(E)}+\left\|u_{0}\right\|_{E}+\left\|u_{N}\right\|_{E}\right]
$$

where $M$ does not depend on $f^{\tau}, u_{0}, u_{N}$ and $\tau$. 


\section{Stability of difference problem (3)}

We consider the difference problem (3). Using formula (5) and the nonlocal conditions

$$
u_{0}=u_{N}+\varphi, \sum_{i=1}^{N} u_{i} \tau=\psi,
$$

we get

$$
\begin{aligned}
u_{0}=(2 I+\tau B)^{-1}\left(I-R^{N}\right)^{-1}\left(I+R^{N}\right)\left\{B \psi-(I+\tau B) B^{-1} \sum_{i=1}^{N-1} f_{i} \tau\right\}- \\
\quad-\left(I-R^{N}\right)^{-1}(I+\tau B)\left(I-R^{N+1}\right)(2 I+\tau B)^{-1} \varphi+ \\
+\left(I-R^{N}\right)^{-1}(I+\tau B)(2 I+\tau B)^{-1} B^{-1} \sum_{i=1}^{N-1}\left(R^{N-i}+R^{N+i}\right) f_{i} \tau \\
u_{N}=(2 I+\tau B)^{-1}\left(I-R^{N}\right)^{-1}\left(I+R^{N}\right)\left\{B \psi-(I+\tau B) B^{-1} \sum_{i=1}^{N-1} f_{i} \tau\right\}- \\
\quad-\left(I-R^{N}\right)^{-1}\left(I-R^{N-1}\right)(2 I+\tau B)^{-1} \varphi+ \\
+\left(I-R^{N}\right)^{-1}(I+\tau B)(2 I+\tau B)^{-1} B^{-1} \sum_{i=1}^{N-1}\left(R^{N-i}+R^{N+i}\right) f_{i} \tau
\end{aligned}
$$

Actually, applying formula (5), we get

$$
\begin{aligned}
\psi= & u_{N} \tau+\sum_{k=1}^{N-1} u_{k} \tau=\left(I-R^{2 N}\right)^{-1}\left\{\sum_{k=1}^{N}\left(R^{k}-R^{2 N-k}\right)\left(u_{N}+\varphi\right) \tau+\right. \\
+ & \sum_{k=1}^{N}\left(R^{N-k}-R^{N+k}\right) u_{N} \tau-\sum_{k=1}^{N-1}\left(R^{N-k}-R^{N+k}\right)(I+\tau B) \times \\
& \left.\times(2 I+\tau B)^{-1} B^{-1} \sum_{i=1}^{N-1}\left(R^{N-i}-R^{N+i}\right) f_{i} \tau^{2}\right\}+ \\
& +(I+\tau B)(2 I+\tau B)^{-1} B^{-1} \sum_{i=1}^{N-1} \sum_{k=1}^{N-1}\left(R^{|k-i|}-R^{k+i}\right) f_{i} \tau^{2} .
\end{aligned}
$$

By computing and interchanging the order of summation, we obtain

$$
\begin{gathered}
\psi=\left(I-R^{2 N}\right)^{-1}(I-R)^{-1}\left\{\left(R-R^{N+1}-R^{N}+R^{2 N}\right)\left(u_{N}+\varphi\right) \tau+\left(I-R^{N}-R^{N+1}+R^{2 N+1}\right) u_{N} \tau\right\}- \\
-\left(I-R^{2 N}\right)^{-1}(I-R)^{-1}(I+\tau B)(2 I+\tau B)^{-1} B^{-1}\left(R-R^{N}-R^{N+1}+R^{2 N}\right) \sum_{i=1}^{N-1}\left(R^{N-i}-R^{N+i}\right) f_{i} \tau^{2}+ \\
+(I-R)^{-1}(I+\tau B)(2 I+\tau B)^{-1} B^{-1} \sum_{i=1}^{N-1}\left(I-R^{i}+R-R^{N-i}-R^{i+1}+R^{N+i}\right) f_{i} \tau^{2} .
\end{gathered}
$$

It follows that

$$
\begin{gathered}
\psi-\left(I+R^{N}\right)^{-1}\left(I-R^{N-1}\right) B^{-1} \varphi=\left(I+R^{N}\right)^{-1}\left(I-R^{N}\right)(2 I+\tau B) B^{-1} u_{N}- \\
-\left(I+R^{N}\right)^{-1}(I+\tau B)(2 I+\tau B)^{-1} B^{-2}\left(I-R^{N-1}\right) \sum_{i=1}^{N-1}\left(R^{N-i}-R^{N+i}\right) f_{i} \tau+ \\
+(I+\tau B)^{2}(2 I+\tau B)^{-1} B^{-2} \sum_{i=1}^{N-1}\left((I+R)\left(I-R^{i}\right)-R^{N-i}+R^{N+i}\right) f_{i} \tau
\end{gathered}
$$


Thus

$$
\begin{aligned}
& u_{N}=(2 I+\tau B)^{-1}\left(I-R^{N}\right)^{-1}\left(I+R^{N}\right) B\left\{\psi-\left(I+R^{N}\right)^{-1}\left(I-R^{N-1}\right) B^{-1} \varphi+\right. \\
& +\left(I+R^{N}\right)^{-1}(I+\tau B)(2 I+\tau B)^{-1} B^{-2}\left(I-R^{N-1}\right) \sum_{i=1}^{N-1}\left(R^{N-i}-R^{N+i}\right) f_{i} \tau- \\
& \left.-(I+\tau B)^{2}(2 I+\tau B)^{-1} B^{-2} \sum_{i=1}^{N-1}\left((I+R)\left(I-R^{i}\right)-R^{N-i}+R^{N+i}\right) f_{i} \tau\right\}= \\
& =(2 I+\tau B)^{-1}\left(I-R^{N}\right)^{-1}\left(I+R^{N}\right) B \psi-\left(I-R^{N}\right)^{-1}\left(I-R^{N-1}\right)(2 I+\tau B)^{-1} \varphi+ \\
& +\left(I-R^{N}\right)^{-1}(I+\tau B)^{2}(2 I+\tau B)^{-2} B^{-1}\left(R-R^{N}\right) \sum_{i=1}^{N-1}\left(R^{N-i}-R^{N+i}\right) f_{i} \tau- \\
& \left.-\left(I-R^{N}\right)^{-1}(I+\tau B)(2 I+\tau B)^{-1}\left(I+R^{N}\right) B^{-1} \sum_{i=1}^{N-1} f_{i} \tau\right\}- \\
& \left.-\left(I-R^{N}\right)^{-1}(I+\tau B)^{2}(2 I+\tau B)^{-2}\left(I+R^{N}\right) B^{-1} \sum_{i=1}^{N-1}\left(-(I+R) R^{i}-R^{N-i}+R^{N+i}\right) f_{i} \tau\right\}= \\
& +\left(I-R^{N}\right)^{-1}(I+\tau B)(2 I+\tau B)^{-1} B^{-1} \sum_{i=1}^{N-1}\left(R^{N-i}+R^{N+i}\right) f_{i} \tau . \\
& \left.=(2 I+\tau B)^{-1}\left(I-R^{N}\right)^{-1}\left(I+R^{N}\right)\left\{B^{N}{ }^{-1}\left(I-R^{N-1}\right)(2 I+\tau B)^{-1} \varphi+\tau B\right) B^{-1} \sum_{i=1}^{N-1} f_{i} \tau\right\}-
\end{aligned}
$$

From that there follow formulas (10) and (11).

Theorem 4. Let $A$ be a strongly positive operator in a Banach space $E$ and $\psi=A^{-1} \sum_{i=1}^{N-1} f_{i} \tau, \varphi=0$. Then difference problem (13) is stable in $C_{\tau}(E)$. For a solution of the difference problem (13) the following stability inequalities holds

$$
\left\|u^{\tau}\right\|_{C_{\tau}(E)} \leq M_{1}\left\|f^{\tau}\right\|_{C_{\tau}(E)},
$$

where $M_{1}$ does not depend on $f^{\tau}$ and $\tau$.

Proof. By Theorem 3 we have the following estimate

$$
\left\|u^{\tau}\right\|_{C_{\tau}(E)} \leq M\left[\left\|f^{\tau}\right\|_{C_{\tau}(E)}+\left\|u_{0}\right\|_{E}+\left\|u_{N}\right\|_{E}\right]
$$

for solution of problem (4). Therefore, to prove the theorem it is sufficient to establish estimates for $\left\|u_{0}\right\|_{E}$ and $\left\|u_{N}\right\|_{E}$. Applying formulas (10) and (11), the triangle inequality and estimates (8), (9), we get

$$
\begin{aligned}
& \left\|u_{0}\right\|_{E} \leq M_{1}\left\|f^{\tau}\right\|_{C_{\tau}(E)} \\
& \left\|u_{N}\right\|_{E} \leq M_{1}\left\|f^{\tau}\right\|_{C_{\tau}(E)} .
\end{aligned}
$$

Theorem 4 is proved.

\section{Application}

Now, we will give the application of Theorem 4 to elliptic equations. Let $\Omega$ be the unit open cube in the $n$-dimensional Euclidean space $\mathbb{R}^{n} \quad\left(0<x_{k}<1,1 \leq k \leq n\right)$ with boundary $S, \bar{\Omega}=\Omega \cup S$. In $[0, T] \times \Omega$ we consider the nonlocal boundary value problem for the multidimensional elliptic equation 


$$
\left\{\begin{array}{l}
-\frac{\partial^{2} u(y, x)}{\partial y^{2}}-\sum_{r=1}^{n} \alpha_{r}(x) \frac{\partial^{2} u(y, x)}{\partial x_{r}^{2}}+\delta u(y, x)=f(y, x) \\
x=\left(x_{1}, \ldots, x_{n}\right) \in \Omega, 0<y<T \\
u(0, x)=u(T, x), \int_{0}^{T} u(s, x) d s=0, x \in \bar{\Omega} \\
\frac{\partial u(y, x)}{\partial \vec{m}}=0, x \in S
\end{array}\right.
$$

where $\alpha_{r}(x) \quad(x \in \Omega)$ and $f(y, x) \quad(y \in(0, T), x \in \Omega)$ are given smooth functions and $\alpha_{r}(x)>0, \delta>0$ is a sufficiently large number. Here, $\vec{m}$ is a normal vector to $S$. The discretization of problem (13) is also carried out in two steps. In the first step, let us define the grid sets

$$
\begin{gathered}
\bar{\Omega}_{h}=\left\{x=x_{j}=\left(h_{1} j_{1}, \ldots, h_{m} j_{m}\right), j=\left(j_{1}, \ldots, j_{m}\right) ;\right. \\
\left.0 \leq j_{r} \leq M_{r}, h_{r} M_{r}=1, r=1, \ldots, m,\right\} \\
\Omega_{h}=\bar{\Omega}_{h} \cap \Omega, S_{h}=\bar{\Omega}_{h} \cap S .
\end{gathered}
$$

We introduce the Banach spaces $L_{2 h}=L_{2}\left(\bar{\Omega}_{h}\right)$ and $C_{h}=C\left(\bar{\Omega}_{h}\right)$ of the grid functions $\varphi^{h}(x)=$ $=\left\{\varphi\left(h_{1} j_{1}, \ldots, h_{m} j_{m}\right)\right\}$ defined on $\bar{\Omega}_{h}$, equipped with the norms

$$
\left\|\varphi^{h}\right\|_{L_{2 h}}=\left(\sum_{x \in \bar{\Omega}_{h}}\left|\varphi^{h}(x)\right|^{2} h_{1} \cdots h_{m}\right)^{1 / 2}
$$

and

$$
\left\|\varphi^{h}\right\|_{C_{h}}=\sup _{x \in \bar{\Omega}_{h}}\left|\varphi^{h}(x)\right|
$$

respectively. To the differential operator $A$ generated by problem (13), we assign the difference operator $A_{h}^{x}$ by the formula

$$
A_{h}^{x} u^{h}(x)=-\sum_{r=1}^{m}\left(a_{r}(x) u_{\bar{x}_{r}}^{h}\right)_{x_{r}, j_{r}}
$$

acting in the space of grid functions $u^{h}(x)$, satisfying the condition $\frac{\partial u^{h}(x)}{\partial \vec{m}}\left(\forall x \in S_{h}\right)$. It is known that $A_{h}^{x}$ is a self-adjoint positive definite operator in $L_{2}\left(\bar{\Omega}_{h}\right)$ and $C\left(\bar{\Omega}_{h}\right)$. With the help of $A_{h}^{x}$, we arrive at the nonlocal boundary value problem

$$
\left\{\begin{array}{l}
-\frac{d^{2} u^{h}(y, x)}{d y^{2}}+A_{h}^{x} u^{h}(t, x)=f^{h}(t, x) ; \\
x \in \Omega_{h}, 0<y<T ; \\
u^{h}(0, x)=u^{h}(T, x), \int_{0}^{T} u^{h}(s, x) d s=0, x \in \bar{\Omega}_{h} ; \\
\frac{\partial u^{h}(x)}{\partial \vec{m}}=0, x \in S_{h} .
\end{array}\right.
$$

In the second step, we replace problem (17) by the second order of accuracy difference scheme (3)

$$
\left\{\begin{array}{l}
-\frac{u_{k+1}^{h}(x)-2 u_{k}^{h}(x)+u_{k-1}^{h}(x)}{\tau^{2}}+A_{h}^{x} u_{k}^{h}(x)=f_{k}^{h}(x), f_{k}^{h}(x)=f^{h}\left(y_{k}, x\right) \\
y_{k}=k \tau, 1 \leq k \leq N-1, N \tau=T, x \in \Omega_{h} \\
u_{0}^{h}(x)=u_{N}^{h}(x), \sum_{i=1}^{N} u_{i}^{h}(x) \tau=0, x \in \bar{\Omega}_{h} .
\end{array}\right.
$$

Using the results of Theorem 4, we can obtain the following theorem. 
Theorem 5. Let $\tau$ and $h$ be sufficiently small numbers and $\sum_{i=1}^{N-1} f^{h}\left(y_{i}, x\right)=0$. Then, solutions of difference scheme (18) satisfy the following estimates

$$
\begin{aligned}
& \max _{0 \leq k \leq N}\left\|u_{k}^{h}\right\|_{L_{2 h}} \leq M_{1} \max _{1 \leq k \leq N-1}\left\|f_{k}^{h}\right\|_{L_{2 h}} ; \\
& \max _{0 \leq k \leq N}\left\|u_{k}^{h}\right\|_{C_{h}} \leq M_{1} \max _{1 \leq k \leq N-1}\left\|f_{k}^{h}\right\|_{C_{h}},
\end{aligned}
$$

here $M_{1}$ does not depend on $\tau, h$ and $f_{k}^{h}, 1 \leq k \leq N-1$.

The illustrative numerical result

When the analytical methods do not work properly, the numerical methods for obtaining approximate solutions of partial differential equations play an important role in applied mathematics.

For numerical analysis, we consider the nonlocal boundary problem for the two dimensional elliptic equation

$$
\left\{\begin{array}{l}
-\frac{\partial^{2} u}{\partial t^{2}}-\frac{\partial^{2} u}{\partial x^{2}}+u=3 \cos t \cos x, \quad 0<t<2 \pi, 0<x<2 \pi \\
u(0, x)=u(2 \pi, x) ; \quad \int_{0}^{2 \pi} u(s, x) d s=0,0 \leq x \leq 2 \pi \\
u_{x}(t, 0)=u_{x}(t, 2 \pi)=0, \quad 0 \leq x \leq 2 \pi
\end{array}\right.
$$

The exact solution of this problem is

$$
u(t, x)=\cos t \cos x .
$$

For an approximate solution of the nonlocal boundary problem (19), we consider the set $[0,2 \pi]_{\tau} \times[0,2 \pi]_{h}$ of a family of grid points depending on the small parameters $\tau$ and $h$

$$
[0,2 \pi]_{\tau} \times[0,2 \pi]_{h}=\left\{\left(t_{k}, x_{n}\right): t_{k}=k \tau, 0 \leq k \leq N, N \tau=2 \pi, \quad x_{n}=n h, 0 \leq n \leq M, M h=2 \pi\right\} .
$$

For a numerical solution, we consider the difference scheme of the second order of accuracy in $t$ and the first order of accuracy in $x$.

$$
\left\{\begin{array}{l}
-\frac{u_{n}^{k+1}+u_{n}^{k}+u_{n}^{k-1}}{\tau^{2}}-\frac{u_{n+1}^{k}+u_{n}^{k}+u_{n-1}^{k}}{h^{2}}+u_{n}^{k}=3 \cos t_{k} \cos x_{n}, 1 \leq k \leq N-1,1 \leq n \leq M-1 \\
u_{n}^{0}=u_{n}^{N}, \sum_{i=0}^{N-1} u_{n}^{i}=0,0 \leq n \leq M \\
u_{1}^{k}-u_{0}^{k}=u_{M}^{k}-u_{M-1}^{k}=0,0 \leq k \leq N .
\end{array}\right.
$$

It is the system of algebraic equations and it can be written in the matrix form

$$
\left\{\begin{array}{l}
A u_{n+1}+B u_{n}+C u_{n-1}=D \varphi_{n}, 1 \leq n \leq M-1, \\
u_{0}=u_{1}, u_{M-1}=u_{M} .
\end{array}\right.
$$

Here,

$$
A=C=\left[\begin{array}{ccccccccc}
0 & 0 & 0 & 0 & . & 0 & 0 & 0 & 0 \\
0 & a & 0 & 0 & . & 0 & 0 & 0 & 0 \\
0 & 0 & a & 0 & . & 0 & 0 & 0 & 0 \\
0 & 0 & 0 & a & . & 0 & 0 & 0 & 0 \\
. & . & . & . & . & . & . & . & . \\
0 & 0 & 0 & 0 & . & a & 0 & 0 & 0 \\
0 & 0 & 0 & 0 & . & 0 & a & 0 & 0 \\
0 & 0 & 0 & 0 & . & 0 & 0 & a & 0 \\
0 & 0 & 0 & 0 & . & 0 & 0 & 0 & 0
\end{array}\right]_{(N+1) \times(N+1)} \quad, B=\left[\begin{array}{ccccccccc}
1 & 0 & 0 & 0 & . & 0 & 0 & 0 & -1 \\
c & b & c & 0 & . & 0 & 0 & 0 & 0 \\
0 & c & b & c & . & 0 & 0 & 0 & 0 \\
0 & 0 & c & b & . & 0 & 0 & 0 & 0 \\
. & . & . & . & . & . & . & . & . \\
0 & 0 & 0 & 0 & . & b & c & 0 & 0 \\
0 & 0 & 0 & 0 & . & c & b & c & 0 \\
0 & 0 & 0 & 0 & . & 0 & c & b & c \\
0 & 1 & 1 & 1 & . & 1 & 1 & 1 & 1
\end{array}\right]_{(N+1) \times(N+1),}
$$

where $a=-\frac{1}{h^{2}}, b=\frac{2}{\tau^{2}}+\frac{2}{h^{2}}+1, c=-\frac{1}{\tau^{2}}$, 


$$
\varphi_{n}=\left[\begin{array}{c}
c \varphi_{n}^{0} \\
\varphi_{n}^{1} \\
\dot{\varphi}_{n}^{N-1} \\
\varphi_{n}^{N}
\end{array}\right]_{(N+1) \times 1}=\left[\begin{array}{c}
0 \\
3 \cos t_{1} \cos x_{n} \\
\cdot \\
3 \cos t_{N-1} \cos x_{n} \\
0
\end{array}\right]_{(N+1) \times 1}
$$

and $D=I_{N+1}$ is the identity matrix,

$$
u_{s}=\left[\begin{array}{c}
c u_{s}^{0} \\
u_{s}^{1} \\
\cdot \\
u_{s}^{N-1} \\
u_{s}^{N}
\end{array}\right]_{(N+1) \times 1} \quad, s=n-1, n, n+1 .
$$

Therefore, to solve the matrix equation (21), we will use the modified Gauss elimination method. We seek the solution of the matrix equation by the following form:

$$
u_{n}=\alpha_{n+1} u_{n+1}+\beta_{n+1}, \quad n=M-1, \ldots, 1,0,
$$

where $u_{M}=\left(I-\alpha_{M}\right)^{-1} \beta_{M}, \alpha_{j} \quad(j=1, \ldots, M-1)$ are $(N+1) \times(N+1)$ square matrices, $\beta_{j} \quad(j=1, \ldots, M-1)$ are $(N+1) \times 1$ column matrices, $\alpha_{1}$ is the identity and $\beta_{1}$ are zero matrices and

$$
\begin{gathered}
\alpha_{n+1}=-\left(B+C \alpha_{n}\right)^{-1} A \\
\beta_{n+1}=\left(B+C \alpha_{n}\right)^{-1}\left(D \varphi_{n}-C \beta_{n}\right), n=1, \ldots, M-1 .
\end{gathered}
$$

Now, we give the error analysis between exact solutions $u\left(t_{k}, x_{n}\right)$ and the approximate solutions $u_{n}^{k}$ for the different values of $N$ and $M$. The errors are computed by the formula

$$
E_{M}^{N}=\max _{0 \leq k \leq N, 0 \leq n \leq M}\left|u\left(t_{k}, x_{n}\right)-u_{n}^{k}\right|
$$

The numerical results for the difference scheme (20) are given in the following tables $1,2$.

Table 1

\begin{tabular}{|c|c|c|c|}
\hline Two dimensional & $N, M=20,20$ & $N, M=40,40$ & $N, M=80,80$ \\
\hline Difference scheme & 0.1329 & 0.0607 & 0.0290 \\
\hline
\end{tabular}

Table 2

\begin{tabular}{|r|c|c|c|}
\hline Two dimensional & $N, M=20,400$ & $N, M=40,1600$ & $N, M=80,6400$ \\
\hline Difference scheme & 0.0029 & $7.1859 e-04$ & $1.7955 e-04$ \\
\hline
\end{tabular}

As it is seen in Table 1, if $N$ and $M$ are doubled, the value of errors decrease by a factor of approximately $1 / 2$. Moreover, as it is seen in Table 2 , if $N$ is doubled and $M \geq N^{2}$, the value of errors decrease by a factor of approximately $1 / 4$ difference scheme as the second order of accuracy.

\section{Acknowledgments}

The publication has been prepared with the support of the «RUDN University Program 5-100» and published under target program BR05236656 of the Science Committee of the Ministry of Education and Science of the Republic of Kazakhstan.

\section{References}

1 Ashyralyev, A., \& Sobolevskii, P.E. (2004). New Difference Schemes for Partial Differential Equations, Operator Theory: Advances and Applications, Vol. 148. Basel, Boston, Berlin: Birkhauser, Verlag. 
2 Skubachevskii, A.L. (1997). Elliptic functional differential equations and applications. Basel, Boston, Berlin: Birkhauser Verlag.

3 Lunardi, A. (1995). Analytic semigroups and optimal regularity in parabolic problems. Basel, Boston, Berlin: Birkhauser Verlag.

4 Kal'menov, T.S., \& Torebek, B.T. (2017). Eurasian Mathematical Journal, 8, 1, 50-57.

5 Ashyralyev, A.I., \& Karatay, P.E. Sobolevskii. (2004). Discrete Dynamics in Nature and Society, 2, 273286.

6 Besbaev, G.A., Orazov, I., \& Sadybekov, M.A. (2014). Electronic Journal of Differential Equations, 203, $1-5$.

7 Ashyralyyev, C. (2017). Boundary Value Problems, 74. DOI: 10.1186/s13661-017-0804-y.

8 Jachimavičiené, J., Sapagovas, M., Štikonas, A., \& Štikonienė, O. (2014). Nonlinear Analysis: Modelling and Control, 19, 2, 225-240.

9 Čiupaila, R., Sapagovas, M., \& Štikonienè, O. (2013). Nonlinear Analysis: Modelling and Control, 18, 4, $412-426$.

10 Sapagovas, M., \& Jakubelienė, K. (2012). Nonlinear Analysis: Modelling and Control, 17, 1, 91-98.

11 Ashyralyev, A. (2017). EO. Beigmohammadi, Numerical Functional Analysis and Optimization, 38, 10, $1244-1259$.

12 Ivanauskas, F., Meskauskas, T., \& Sapagovas, M. (2009). Applied Mathematics and Computation, 215, 7, 2716-2732.

13 Ivanauskas, F.F., Novitski, Yu.A., \& Sapagovas, M.P. (2013). Differential Equations, 49, 7, 849-856.

14 Shakhmurov, V., \& Musaev, H. (2017). Applied and Computational Mathematics, 16, 2, $190-200$.

15 Sapagovas, M., Griskoniene, V., \& Štikonienè, O. (2017). Nonlinear Analysis: Modelling and Control, 22, 4, 489-504.

16 Ashyralyev, A., \& Tetikoglu, F.S. (2017). Numerical Functional Analysis and Optimization, 38, 10, 13251340 .

17 Ashyralyev, A., \& Tetikoglu, F.S.O. (2014). Mathematical Methods in the Applied Sciences, 37, 17, 26632676.

18 Azarnavid, B., \& Parand, K. (2018). Journal of Computational and Applied Mathematics, 328, $151-163$.

19 Avalishvili, G., Avalishvili, M., \& Miara, B. (2018). Complex Variables and Elliptic Equations, 63, 6, 836-853.

20 Avazpour, L. (2018). Journal of Inequalities and Special Functions, 9, 2, 15-29.

21 Ashyralyev, A., \& Abdizhahan, S.M. (2015). Electronic Journal of Differential Equations, 284, 1-8.

\section{А. Ашыралыев, А. Хамад}

\section{Эллипстік теңдеулер үшін локалдық емес шеттік есептерді сандық шешу}

\footnotetext{
Мақалада қатаң оң $A$ операторы бар эллипстік теңдеу үшін мына түрдегі $-v^{\prime \prime}(t)+A v(t)=f(t)$, $(0 \leq t \leq T), v(0)=v(T)+\varphi, \int_{0}^{T} v(s) d s=\psi$ локалдық емес шеттік есепті жуықтап шешуге арналған екінші ретті дәлдігі бар екі адымды айрымдық схема келтірілген. Есеп қандай да бір Е Банах кеңістігінде қарастырылды. Айрымдық схеманың орнықты болатыны көрсетілген. Қосымшада шеттік шарттары Нейман түріндегі дифференциалды есеп үшін айырымдық схема шешімінің орнықтылығын бағалаулар көрсетілген. Сондай-ақ сандық есептеулердің нәтижелері берілген.

Kiлm сөздер: орнықтылық, оң операторлар, эллипстік теңдеулер, сандық нәтиже, екінші ретті дәлдігі.
} 
А. Ашыралыев, А. Хамад

\section{Численное решение нелокальной краевой задачи для эллиптических уравнений}

В статье представлена двухшаговая разностная схема второго порядка точности для приближенного решения нелокальной краевой задачи для эллиптического дифференциального уравнения $-v^{\prime \prime}(t)+A v(t)=f(t) \quad(0 \leq t \leq T), v(0)=v(T)+\varphi, \int_{0}^{T} v(s) d s=\psi$ в произвольном банаховом пространстве $E$ с сильно положительным оператором $A$. Установлена устойчивость этой разностной схемы. В приложении получены оценки устойчивости решения разностной схемы для эллиптической дифференциальной задачи с граничным условием Неймана. Кроме того, приведен демонстрационный численный результат.

Ключевые слова: устойчивость, положительные операторы, эллиптическое уравнение, численные результаты, двухшаговая разностная схема. 